Acta Poetica 24

2003

Carmen Leñero

\title{
Palabra poética y teatralidad
}

La poesía es un caracol en un rectángulo de agua.

José Lezama Lima

Resumo en este artículo las hipótesis y conclusiones de un trabajo de investigación titulado "Rasgos de teatralidad en textos no dramatúrgicos", donde he analizado discursos pertenecientes a diversos géneros: los diálogos filosóficos de Martín Heidegger, ${ }^{1}$ el poema místico de San Juan de la Cruz, ${ }^{2}$ el discurso confesional de San Agustín ${ }^{3}$ y de Ludwig Wittgenstein, ${ }^{4}$ y el discurso adivinatorio en el Oráculo de Delfos 5 .

La noción de teatralidad, entendida en términos amplios como un modo de representación del mundo, orienta mi lectura de los textos; da cuenta del modo en que funciona en

${ }^{1}$ En Serenidad; De camino al habla y Caminos del bosque.

2 "Cántico espiritual" y "Noche oscura del alma".

${ }^{3}$ Confesiones, Círculo de lectores, Barcelona, 1971.

${ }^{4}$ Diarios secretos (edición de la parte izquierda de los Cuadernos).

5 Reconstruido a partir de documentos históricos (Plutarco, Herodoto, Hesíodo, Heráclito, Platón, etc.), citas en obras y tragedias clásicas así como en dos obras de ficción contemporánea: Dürrenmatt, La muerte de la Pitia, y Christian Woef, Cassandra. 
ellos la palabra y revela las dinámicas peculiares que se dan entre los signos, cuando se concibe al "texto" (ya sea literario, filosófico, mágico o religioso) como "espacio de encuentro" entre subjetividades, y a su palabra viva, actuante, como "palabra poética".

\section{La palabra poética}

A menudo me he preguntado sobre el peso de las palabras y los vínculos que generan entre los hombres dependiendo de las circunstancias concretas en que son dichas, oídas o leídas, y en especial cuando estos vínculos son de carácter estético. Es decir, cuando deliberadamente involucran la sensibilidad del enunciador y del interlocutor, para provocar más un "percibir" que un "saber"; más una experiencia que un conocimiento. Si la palabra no sólo remite a una experiencia objetiva con las cosas, sino ejerce la capacidad de actualizar una experiencia subjetiva ante el escucha o el lector, haciéndolo participar vívida pero reflexivamente en ella, la llamo palabra poética. Más allá de operar como un signo (inteligible dentro de un código determinado), la palabra poética es un espacio de encuentro y provocación, un espacio de la intersubjetividad donde la verdad adquiere un estatus vacilante, provisional pero incitador.

Creo que la función poética de la palabra puede darse en diferentes contextos orales y escritos, y no sólo en los que reconocemos como "poemas" o textos literarios. La palabra es poética cuando tiene la facultad de generar una experiencia de los sentidos aunada al intelecto, una experiencia que integra cuerpo y mente; cuando su "significación", más allá de su contenido conceptual, depende de sus características formales, sonoras, gráficas, simbólicas, es decir, de su música y aparición misma, así como de las resonancias anímicas que provoca; cuando la relación que establece entre las personas no tiene 
fines utilitarios - ya sean políticos, didácticos o terapéuticos; cuando nombra y describe al mundo sólo de manera tentativa, no definitoria; cuando es cauce abierto de contenidos emocionales; cuando sitúa a quienes participan de ella en una perspectiva que rebasa sus roles sociales, su personalidad, su bagaje cultural y su psicología individual para adentrarse en el ser colectivo y misterioso que somos; y finalmente, cuando el hecho de emitirla y el de recibirla constituyen un solo acto de participación.

Si es verdad que la "significación" de todo lo que percibimos es primordialmente afectiva, ${ }^{6}$ y que de esa valoración primera dependen las ideas que tendremos sobre las cosas, así como la imagen mental en que las "reconocemos", la palabra poética más que describir el mundo de manera abstracta intenta recuperar la experiencia sensible y pasional, corporal y concreta por la que atravesamos al entrar en contacto con él. El texto con características poéticas se constituye pues en un "acontecimiento".

Tendemos a creer que la existencia de las palabras es inmaterial, que están constituidas por sus significados abstractos, codificados, que están cerradas sobre sí mismas como volutas etéreas, como objetos incorpóreos y muertos o monedas con cierto valor convencional que intercambiamos a través del aire, la hoja escrita o el cable. Pero su existencia y su poder son muy concretos: generan procesos en nuestra fisiología y en nuestra psique, como la aparición de imágenes en el cere-

\footnotetext{
${ }^{6}$ Esta valoración afectiva, núcleo de la significación o del sentido, se origina en el modo en que una realidad cualquiera responde o no a nuestras necesidades primarias: alimento, seguridad, autoestima, necesidades que se van volviendo más complejas al imbricarse con otras experiencias, y con los signos que se les asocian, según dicen los más recientes estudios sobre fenómenos cognoscitivos: El sistema límbico (responsable de procesar las emociones y reacciones que la realidad nos produce) es la "memoria organizadora" de los conceptos, formas y significados abstractos a nivel de los lóbulos frontales. Así pues, reconocer estas formas a nivel intelectual no significa comprender su significado (Cfr. Ramachandrán, Fantasmas en el cerebro.
} 
bro, el crecimiento de redes neuronales, cambios en nuestro sistema inmunológico y en nuestros estados de ánimo, sin hablar de nuestras actitudes voluntarias. Las palabras están vivas, ya sea en el aire, el papel, la piedra o la pantalla, y si acaso "muere" su capacidad de provocar experiencia, también contaminan de muerte nuestra imaginación y organismo.

Para el estudio de esta "palabra viva" y actuante me ha sido útil adoptar una noción amplia de teatralidad y categorías que se desprenden de una reflexión semiológica sobre lo teatral, cuyo objeto básico de estudio es "el acto en situación" que se "da a ver".

La palabra poética quiere usar los poderes del lenguaje pero sin apoderarse de nada. Para ello debe procurar de mantenerse viva, es decir abierta a la reinterpretación, y a la vez de no desear obtener nada para sí misma o para quien la esgrime. ¿Y cómo es que una palabra permanece viva, poderosa e "inocente" a un tiempo? ¿Cómo vence la erosión de las edades, el peso lapidario de los saberes, la caducidad inevitable de los conceptos que arrastra, o los restringidos intereses individuales de quien la usa? ¿Cómo vence la inmaterialidad, la abstracción, la separación con la vida cotidiana? ¿Cómo elude ser esclava y cómplice de los poderes superestructurales que se han apropiado de ella para apropiarse de nosotros? ¿Cómo vuelve a ser "nuestra"?

El significado de una palabra no sólo radica en los contenidos que históricamente ha acumulado y es capaz de traer al presente, sino de la calidad y circunstancia de la voz que la emite, de la posición del sujeto, de la atmósfera en que resuena, y sobre todo, de la tensión que desata. La palabra poética se hace especial cargo de eso. Y por lo mismo, en un poema escrito la palabra intenta recuperar para sí misma una voz, un estado de ánimo concreto, un cuerpo de percepciones sensibles, un tiempo y un espacio en que se actualiza como cosa viva, como una acción que se verifica en el universo provisio- 
nal que genera el poema, ámbito para ser visitado por otro ser humano en calidad casi de espectador. Y se le puede llamar "espectador" porque lo que ocurre al lector ante un poema "vivo" le ocurre en el presente en que lee y para la integridad de sus sentidos y su mente.

La experiencia del poema comienza por la sorpresa de ver cómo el pensamiento (que no suena) y la música (que sí suena) se han fundido en un mismo fenómeno. Tenemos la falsa ilusión de que la música es inmaterial y de que el pensamiento es atemporal, pero la presencia de las palabras y su énfasis en su propia corporeidad (su ritmo, sus consonancias, sus contrastes, sus "padecimientos") nos recuerda que se trata de "objetos vivientes", capaces de provocar cambios en nosotros, por muy imperceptibles que nos resulten.

No sólo en los poemas la palabra regresa al mundo de las sensaciones y los contactos. Hay otras situaciones milagrosas en que la palabra se corporeiza, y retoma su poder de penetrar; en este "regreso" a la materia, la prosa, la filosofía, la ciencia, la profecía, operan como poesía también. Más que configurar discursos o relatos se convierten en "actos" de provocación donde el escritor y el lector quedan estrechamente involucrados, participando de una experiencia común más allá de sus preocupaciones y anhelos individuales, y quizá explorando juntos una perspectiva nueva de lo que les rodea e incumbe.

La palabra poética puede no sólo materializar una geografía o actualizar una historia, sino que despliega a menudo un $\mathrm{dra}$ ma: el drama de su incapacidad para expresar un sinnúmero de aspectos de la realidad; el de nuestra separación como individuos respecto del mundo; la fatal dicotomía entre lo objetivo y lo subjetivo; nuestra participación involuntaria en una cultura que en ciertos niveles nos constriñe, o incluso la contradicción entre nuestra mortalidad y el aliento intemporal que nos anima. 


\section{La teatralidad}

Para observar este comportamiento de la poesía, para considerar a la palabra como un "hacer" más que como un "referirse a" he adoptado una estrategia: leerla como si la escuchara dicha por alguien en medio de una escena implícita; e indagar cómo es el clima emocional, el ritmo de acción, la tensión dramática, y en suma, la teatralidad intrínseca a esa escena que la palabra está generando.

Habilitar la analogía entre texto escrito y escena me llevó a considerar la teatralidad no sólo como origen del quehacer teatral concreto, sino como un modo de representación integral que no procede por secuencia sino por sincronía, ${ }^{7}$ y que manifiesta nuestra facultad de imaginar un micromundo virtual, de transmitirlo tal como lo percibe un sujeto in situ, y en términos de un acontecer en tiempo presente para el interlocutor.

Ha sido útil, pues, explorar la palabra poética en sus virtuales atributos tridimensionales: su ubicación, textura, dinámicas y resonancias, como si se tratara de un fenómeno teatral. Esto implica emplear el teatro como metáfora, sí, pero no a un nivel meramente retórico. Dado que el teatro se hace con los ingredientes de la realidad material: espacio, tiempo, cosas, cuerpos, voces, contactos, movimientos, tensiones, todos ellos elementos que se condensan y exponencian con el fin de ser intensamente percibidos; y dado que el teatro no es sólo espejo de la realidad, sino laboratorio y crisol de nuevas vivencias de lo real, una extrapolación de la experiencia teatral al terreno bidimensional de la escritura puede dar cuenta de la significa-

\footnotetext{
${ }^{7}$ Al hablar de la sincronicidad, en oposición a la causalidad, como lógica de validación de los discursos, Jung explica cómo la convergencia y simultaneidad de los signos es lo que produce su sentido. Ello sucede palpablemente en ámbitos como el poético y el profético. Lo que le da valor a los signos, indicios o señales es que se produzcan a un mismo tiempo. Este "presente" que otorga sentido se relaciona estrechamente con la representación teatral.
} 
ción de la palabra poética en tanto que "cosa viva y generadora de mundo".

Por supuesto que no cualquier texto, ni siquiera un texto expresamente literario puede concebirse en su "dramaticidad", pero hay condiciones que lo facilitan: el hecho de que presente intensas huellas de oralidad y una puesta en situación de los participantes como "voces" del texto. Los textos que analicé están emparentados muy de cerca con las dinámicas de la conversación y con una circunstancia social concreta, un rito, un sacramento o un espectáculo; todos ellos hacen, además, una constante referencia al entorno físico y a la temporalidad como cauce de desarrollo, más allá de la mera estructuración lógica de sus partes. Por añadidura, aluden de manera explícita al interlocutor y a su posición frente al discurso.

Es cierto que estas características pueden hallarse más o menos latentes en casi todos los textos. Es una cuestión de grado: cuanto más presente esté la voz como realidad sonora, más tangible el cuerpo que la emite, más visibles el espacio y ritmo en que ocurren las cosas, y más involucrado el sujeto en su palabra, ${ }^{8}$ es más factible reconstruir la escena que el texto despliega. El texto se constituye entonces en una especie de territorio ceremonial y opera como mediador entre la referencia abstracta y la experiencia sensible, participando así de la llamada "magia" teatral: encarnar lo ausente, darlo a ver y permitir que ello actúe en el espectador.

\section{Rasgos de lo teatral}

Meditando sobre la especificidad del arte teatral, pero en términos suficientemente abstractos como para aplicar su pers-

\footnotetext{
${ }^{8}$ Un sujeto concreto, con una voz, un cuerpo, un ethos, que suscribe su decir, intensamente comprometido en una situación específica de habla con el receptor $y$ el referente.
} 
pectiva a otros géneros, he establecido siete rasgos propios de la teatralidad:

\section{Generar un espacio y un tiempo de excepción concretos}

— es decir, materiales, mesurables_-, separados del espacio y tiempo reales: un ámbito virtual concebido además como un aquí-ahora. El tiempo y el espacio se comprimen y densifican formando un nuevo "segmento" de realidad -al que llamamos ficción- que se sobrepone a la realidad cotidiana de los espectadores.

2. Hacer converger en un mismo ámbito elementos de distinta naturaleza o sustancia (palabras, imágenes, cuerpos, movimientos), con posibilidad de modificarse y transmutarse unos en otros, y que se conjugan para formar un "signo" muy peculiar: "el acto en situación" (unidad no discreta ni articulada). Lo teatral configura una "imagen" global, en tanto que montaje de traducciones entre diversos lenguajes (el del autor —escritural—, el del director —oral y "arquitectónico"-, el del actor — corporal y emotivo—, quienes se "interpretan" y reinterpretan recíprocamente). El acto-en-situación no sería propiamente un signo, de valor inequívoco y en referencia a un código establecido, sino un haz de señales que aparecen al mismo tiempo ante el espectador, quien también las traduce y reinterpreta.

3. Provocar la comparecencia de tres instancias o sujetos de experiencia y percepción: el personaje (quizá proyección o personificación de alguna de las voces del dramaturgo), el actor $\mathbf{y}$ el espectador, quienes en determinados momentos trasmutan sus funciones, gracias al habitual vaivén entre identificación y distanciamiento, y a la propia dinámica de la actividad mimética. Las tres instancias interactúan: la acción del personaje es ser, la del actor, simular, y la del espectador, ver (involucrarse intensamente pero reconocer a distancia. La presencia positiva del espectador da cumplimiento y sentido al 
acto-en-situación que se "da a ver". Por eso, lo teatral se refiere menos a un "texto" susceptible de ser interpretado que a un "acontecimiento" en el que se participa: el hecho teatral.

4. Actualizar y desplegar un antagonismo esencial entre dos poderes (personajes, principios o fuerzas) opuestos, ${ }^{9}$ tensión que funciona como eje de la creación de sentidos, organizando todo gesto, acción, parlamento e imagen en un microuniverso paradójico pero inteligible, y aportando vitalidad emotiva al conjunto.

5. Negar (también paradójicamente) el carácter de "signos" que se supone tienen los elementos que participan en la escena, al anular la supuesta dicotomía del signo: significante presente/ significado ausente. Sucede que el significante (i.e. la voz y el cuerpo del actor moviéndose en un escenario concreto y en medio de una situación determinada) es de hecho el significado y está efectivamente sucediendo ante nuestros ojos. La convención que prevalece a nivel comunicativo dice: “el valor de lo que se presenta aquí es 'hipotético'; se trata de una situación que ha de experimentarse "como si fuese real". El "como si" del teatro es lo que posibilita la vívida percepción de lo ausente. (Este "como si" es muy diferente al "en lugar de": un papel teatral no se recita ni se relata, se juega).

Así pues, la representación teatral reunifica lo separado en el signo - la parte presente y el referente ausente u oculto-, y reunifica a los "signos" entre sí (los hace actuar al unísono). Por efecto de lo teatral equivalen parlamento y gesto (ambos son "acción" que propician trama); se reúnen personaje y actor, así como nombre, imagen y cuerpo; se reencuentran pala-

\footnotetext{
${ }^{9}$ Las fuerzas en conflicto están activas simultáneamente (por ejemplo, el bien y el mal). Sin embargo, y puesto que la escisión radica en el origen mismo de toda teatralidad: ser y verse ser, actuar y contemplarse, estar identificado y distanciarse, ser objeto y sujeto -no sólo como suceso de conciencia sino de existencia- el conflicto bien puede darse entre un principio activo y otro pasivo (por ejemplo, lo voluntario y lo fatal, lo masculino y lo femenino, Dios y el hombre, etc.)
} 
bra y voz (realidad espiritual, invisible, y realidad física, sonora). La representación es una vuelta a la materia, la carne y el tiempo. De esta característica esencialmente paradójica del hecho teatral dependen las dinámicas de identificación y distanciamiento que se dan entre los sujetos participantes (actores y público), y de aquí también surge su capacidad para mostrar y hacernos ver lo oculto, lo inaccesible, lo censurado.

6. Servir de mediación con esferas sobrenaturales o comúnmente inaccesibles —religiosas, míticas, históricas o inconscientes. No es que simplemente se aluda a lo sagrado o a lo desconocido, sino que se propicia un contacto efectivo con esa dimensión — el mundo de los muertos, los dioses, los fantasmas, los demonios, las fuerzas psíquicas más recónditas, los instintos. ${ }^{10}$

7. Propiciar la metamorfosis de las "sustancias" (elementos verbales, ideas, personajes, cuerpos, actos, puntos de vista) que se ven involucradas en el hecho teatral. Es quizá la propia tensión dramática la que acelera, como un catalizador, los procesos que su puesta en relación desata dentro de un contexto "simulado", transfigurándolos. ${ }^{11}$ De ahí que lo teatral sea concebido como "laboratorio de las pasiones" — para un Stanislavsky; "crisol alquímico de esencias" — para un Artaud; o "metáfora del delirio" — para un Pirandello.

10 Considérese el origen ritual y sacramental de todo teatro, y la pervivencia de este rasgo aún en el teatro profano, la comedia y los diferentes géneros teatrales contemporáneos.

11 Así por ejemplo, una cierta iluminación transforma una atmósfera pública en un ámbito íntimo; una prenda de vestir sustituye a un hombre; una calle se convierte en trayectoria de una vida, una palabra se condensa en un objeto emblemático que se extravía o reencuentra, una pasión se trastoca en su contrario a una velocidad exponenciada, en fin. 


\section{Teatralidad y experiencia poética}

En síntesis, mi noción de "teatralidad" como perspectiva de estudio tiene los siguientes puntos de partida:

- Lo "teatral", si bien se realiza primordialmente en la pieza dramática y el hecho escénico, puede entenderse de manera más amplia como una modalidad de representación correspondiente a una modalidad de pensamiento tridimensional, holística $^{12}$ (distinta a una modalidad secuencial asociada al relato y el discurso lógico — que se despliega a través del tiempo, explicando, justificando, deduciendo, reflexionando- y distinta también a otra modalidad más bien orgánica o estructural, asociada al poema, al esquema, a la gráfica matemática, a la pintura - que se despliega en el plano espacial, bidimensional, ya como panorámica que permite analizar y relacionar, ya como "golpe de vista" que ofrece una comprensión súbita y sintética).

- La modalidad "teatral" de pensamiento es una modalidad escindida, pues nace de la convivencia entre dos movimientos antagónicos de la conciencia: ser y mirarse ser, dentro de un espacio virtual. Por eso ofrece la posibilidad de confrontar posturas, probar alternativas, simular contextos, integrar contradicciones, prever situaciones, vaticinar, interpretar dialógicamente y experimentar como propia una circunstancia “ajena”, con su estela de emociones, sensaciones e ideas. Más allá de su dinámica especular o mimética, la teatralidad es una forma de conciencia que propicia no sólo el descubrimiento o reconocimiento de una realidad, sino la conversión del sujeto

\footnotetext{
12 Cualquiera de nosotros puede aprender a distinguir cuándo su percepción está actuando de manera secuencial, o bien holística. La diferencia radica, explican los neurólogos, en el distinto proceder de cada uno de los hemisferios cerebrales: el izquierdo para el lenguaje lineal y abstracto; y el derecho para la percepción tridimensional que integra la información que aportan los cinco sentidos a un tiempo.
} 
(un "yo") en objeto de su propia observación (un "él”) y sobre todo en otro sujeto distinto (un "tú", transindividual), tal y como sucede en los ritos funerarios, de iniciación, políticos, en las ceremonias sacrificiales ${ }^{13}$, en los socio y psicodramas, así como en los procesos de la creación artística.

- La "teatralidad" puede quizá enriquecer nuestras nociones de lectura y recepción, y dar luz sobre temas como la distancia entre experiencia y expresión, el tránsito entre oralidad y escritura, la delimitación de géneros, el estatus y dinámica de los signos en un texto, la ficción en tanto elaboración transformadora de la conciencia, la virtualidad como condición de un saber integrado a la existencia, etc. Y puede también ayudar a describir muchos procedimientos de creación verbal en la poesía, el ensayo, la narrativa, el diario, la epístola, el aforismo, el diálogo, la profecía.

- Conocer sin ver (reconocer sin sentir) es la ilusión racionalista que la experiencia del teatro desenmascara como práctica estética y enfoque teórico. En el teatro el "significado" está anclado en la emoción, tal y como sucede en nuestro cerebro. ${ }^{14}$ Así pues, la "verdad" de una obra o la autenticidad de un signo es sentida como "calor", como intensidad, ebullición de la propia materia significante, más que como adecuación a ideas preconcebidas o a una visión del mundo. Contrariamente

\footnotetext{
${ }^{13}$ El sujeto que participa en un rito sacrificial, por ejemplo, se ve representado en el objeto de sacrificio (el cordero, el dios, el criminal) y es a la vez testigo de su propia inmolación transferida y colectivizada.

${ }^{14}$ Cuando el canal que conecta al sistema límbico (responsable de la percepción y registro de las emociones) con las restantes estructuras cerebrales se ve dañado, nuestra mente interpreta las señales sensoriales como signos vacíos (vacíos de su valoración emocional); entonces, tales señales o signos son experimentados como apócrifos pues no nos causan las reacciones fisiológicas y anímicas con las que están asociados en nuestro interior. No es necesario que tales reacciones físicas sean aparatosas o deliberadas; a veces son muy sutiles: cambios químicos, enzimáticos, hormonales, que incluso pueden ser medidos por instrumentos; tal es el caso de una microscópica exudación llamada "respuesta galvánica de la piel", los movimientos oculares, las alteraciones del ritmo cardiaco y respiratorio o los impulsos eléctricos en el cerebro.
} 
a lo que se piensa al hablar de "teatralidad" o de histrionismo, la ficción teatral no pretende imitar la realidad pero tampoco traicionarla; pese a que se basa en el fingimiento y la redundancia, su operación estética consiste en condensar e intensificar diversos aspectos de lo real para volverlo más perceptible, autoconsciente y acaso transformable. Su efecto de sentido es ante todo un incremento de la atención en el espectador. Los procedimientos del teatro recuperan para la materia, las palabras y las cosas, el sentido o valor emocional que hubiesen perdido bajo los estereotipos, los prejuicios o la abstracción. Y revelan cómo éstos obnubilan la percepción y enajenan nuestro contacto íntimo con el mundo y el lenguaje.

- Llamo "palabra poética" a la palabra eficaz no sólo para transmitir la peculiaridad de una experiencia, sino para modificar lo que nombra, como un instrumento del conocimiento, la voluntad y el deseo. Su poder de incitación depende en gran medida de lo que calla. La tensión que establece con lo inefable es lo que aumenta su vitalidad, su "cólera". Recupera voz y silencio, como hace la música, silencio de "escucha". El sujeto que la enuncia" habla también "por otros" y así funciona como un actor, como un medium.

- Es factible extrapolar los rasgos de teatralidad para analizar textos donde los elementos visuales, verbales, sonoros, táctiles puedan interpretarse en términos de un proceder, lo que obliga a toda idea a temporalizarse, espacializarse, corporeizarse. Así concebida, adopto la teatralidad no sólo como horizonte de interpretación, sino como modelo para mi propia interpretación y escritura.

\footnotetext{
15 Su elocución está siempre sincopada por la pausa que aguarda la palabra del otro, un otro semejante o trascendente (Dios, el Ser, un personaje histórico, un familiar muerto, el inconsciente colectivo, la voz del pueblo, etc.)
} 
V. "Escena" invisible de la palabra poética en el diálogo filosófico, la confesión, el poema místico y el discurso oracular.

Sabiduría que no pasa por los sentidos no produce sino una verdad destructiva.

Leonardo Da Vinci

La búsqueda de aspectos asociados con lo teatral hace retornar nuestra mirada a la literalidad. Los signos lingüísticos se potencian, intensificando su autoreferencialidad, tornándose en cierto sentido "icónicos" y desandando así el camino del metalenguaje. ${ }^{16}$ Las palabras se aproximan a las cosas, y a sus efectos emocionales directos, y eso crea un tipo de "reconocimiento" renovado. Se rescata para los textos cierta forma de "inocencia" elocutiva. ${ }^{17}$

\section{La palabra como lugar: espacio de encuentro}

Una de las características más sobresalientes en los textos que he estudiado es la configuración mediante el lenguaje de un espacio explícito, con características materiales precisas. Más allá de su carácter metafórico, los espacios descritos y habitados por las voces del texto lo convierten en ámbito de experimentación. Ello tiene que ver con aspectos tan concretos como el uso de tiempos verbales, con el punto de vista adoptado

\footnotetext{
16 "En el teatro, el cuerpo representa un cuerpo, y la voz, una voz; el tiempo en que transcurren, tiempo; y el espacio escénico, espacio también. Por eso en el teatro significante y significado comparten su sustancia y su forma; se identifican y niegan mutuamente". (Leñero, Carmen, La luna en el pozo, p. 24).

${ }^{17}$ Ya desde el Cratilo de Platón, la mítica relación natural entre los nombres y las cosas se opone a la mera convención de la lengua (la arbitrariedad del signo). La palabra poética, tanto como su "teatralidad", intentarían religar íntimamente nombre y cosa. El suyo es, pues, un camino de regreso a esa relación soñada en que la palabra hace presente si no a la cosa misma que nombra, sí al menos a la experiencia sensible de estar en contacto con ella.
} 
para una descripción, con el género (y por tanto con la forma de elocución puesta en marcha), etc.

En sus Diálogos, Heidegger y su interlocutor se adentran por las veredas del bosque y su reflexión se atiene a los avatares de esa geografía; llegan finalmente a un "Claro" donde se detienen a esperar el advenimiento (gratuito) de la verdad como una aparición. La experiencia del Ser se invoca en términos de expectativa visual. Conocer el Ser, entrar en contacto con él equivale a verlo, y adquiere así el valor de una percepción definitiva -y no de una mera especulación tentativa- que irrumpe y modifica la existencia de quien "ve". La caminata de los filósofos genera (como las acciones de un actor generan un escenario, en mayor medida que la misma "escenografía") un horizonte de pensamiento al que Heidegger alude como "Comarca", amplitud que nos sale al encuentro, espacio de intersubjetividad que se despliega conforme transcurre la reflexión dialéctica. "Camino" es esta manera de inquirir, responder y discutir con entusiasmo sereno que el texto de Heidegger pone en ejercicio. Y es en virtud de ese camino, con sus veredas sinuosas, entrecruzadas y circunloquios, que adquiere sentido su formulación del "Habla" (lenguaje fundido a una voz) como "Casa del Ser", al igual que su meditación sobre el arte como "ámbito donde resuena el encantamiento proveniente de los pétalos de Koto". ${ }^{18}$

La dramatología suele distinguir entre espacios explícitos e implícitos en la representación de una obra teatral. Los explícitos estarían dados por la trama, la historia, los parlamentos -ilustrados o no en la escenografía-, y los implícitos estarían dados por la atmósfera emocional creada por los actores y el contexto de recepción encarnado por los espectadores. Si trasladamos estas nociones al espacio textual del Cántico espi-

\footnotetext{
${ }^{18}$ Koto en japonés significa silencio, silencio como atmósfera llena de significado, y que se asocia en el "Diálogo sobre la esencia del arte" (en Serenidad) con las propiedades de una flor.
} 
ritual de San Juan de la Cruz, observamos que el escenario explícito donde transcurre el poema es el mundo entero con sus valles, montañas, ríos, cielos, desiertos, jardines y todas sus criaturas. En este escenario, que se presenta como extremadamente fugaz, ocurre la cacería entre el Amado y la Amada, la búsqueda, la huida, el extravío, la pérdida renovada. También se mencionan espacios cerrados, protegidos, como la bodega, el "lecho florido de flores esmaltado", la "cristalina fuente", en que habrá de darse o se habría dado el encuentro amoroso; y espacios todavía más íntimos, corporales, donde ese encuentro se vuelve sensación pura: los brazos del Amado, los ojos, el cuello, y quizá también aquel metafórico "huerto" del sexo, la "espesura", el árbol bíblico. Pero el espacio implícito en que todos estos espacios se condensan es la interioridad más recóndita del alma: "las hondas cavernas de la piedra", con sus túneles y porosidades, ámbito que parece materializarse en una cárcel real de Toledo donde se encontraba Fray Juan mientras componía el Cántico en voz baja.

En los Diarios secretos de Wittgenstein los espacios explícitos son el barco de guerra donde navega y los escenarios de la Primera Guerra en que se alistó como voluntario, los recintos de reclusión militar y burocrática que le constreñían, o incluso el ámbito escritural, liberador, que se materializa en la parte derecha e izquierda de su Cuadernos; pero el espacio implícito es la conciencia misma del filósofo, donde se despliega la trama entre sus pasiones, instintos e ideas. El espacio explícito de las Confesiones agustinianas es esa "privacidad pública" de un confesionario, cuarto oscuro que atemoriza como un sarcófago. Y sin embargo, el espacio implícito en todo acto de confesión es el desierto, la desnudez misma como escenario vacío e interioridad ardiente a un tiempo, que la escritura de San Agustín evoca de continuo.

El escenario oracular en Delfos es el ádyton, recinto subterráneo del Santuario, a su vez enclavado en un paisaje natural que 
recuerda un útero. Ahí se profiere la palabra de la Pitia, maternal y despiadada. El ádyton, con sus humos alucinógenos —el famoso pneuma - que emergen del subsuelo por una grieta, se convierte en otra suerte de interioridad mítica asociada con el nacimiento, la revelación y el destino, cuya atmósfera asfixiante y extática se traslada después al escenario de la tragedia antigua, así como a la memoria íntima del poeta clásico.

El teatro nace en el espacio, porque ahí se encuentran actor y espectador. Cuando el texto genera virtualmente este espacio, se convoca de igual suerte la comparecencia del lector. Lo que el texto demanda de él es un curioso modo de participación, una "pasividad activa": escuchar las voces y ver las imágenes que aparecen en su conciencia durante la lectura o la rememoración. Cuando la palabra, con su despliegue espacial se orienta hacia la visión más que hacia la intelección, su estatus es el de provocación lumínica; su presencia es señal que apunta hacia sí como "sitio" donde ha de concebirse una vez más el sentido.

La palabra como temporalidad: kinesis de los signos (memoria, actualización y olvido)

Si la palabra crea un espacio vital de encuentro, tal encuentro no puede realizarse sino en virtud del tempo propio de las emociones que lo atraviesan.

Así, la puesta en diálogo de Heidegger se sujeta al ritmo de la caminata; su efecto meditativo viene de la alternancia de los pasos, así como de las réplicas mutuas entre voces que "hacen camino" mientras conversan. La ligereza física y anímica de quien conversa al caminar modela el curso del pensamiento, impidiéndole detenerse en un concepto o fijarse en una noción, y permitiéndole integrar las desviaciones y pausas de un andar despreocupado.

El tempo en que suceden las imágenes en el poema de San Juan de la Cruz es crucial, pues arrebata y cautiva todo signifi- 
cado con su aceleración y fluidez de agua, para verterlos como forma pura en los poros de la piedra. El Amado se transforma en ciervo, paloma, reflejo, mirada, cobijo, ausencia. El alma sale de su casa y se interna extraviada y presta, en la noche oscura. Impulsando las metáforas de una a otra, sin quedarse con ninguna, la escritura poética de San Juan usa los signos sensibles para abandonarlos de inmediato; vacía los nombres y llena los oídos del alma sólo con una liquidez vertiginosa y musical. La unión mística entre el Alma y el Esposo (momento que no puede datarse ni describirse en ningún tiempo verbal perfecto y puntual) es el núcleo en torno al cual gira esta dinámica.

Frente a la velocidad de la formulación mística de San Juan podríamos reconocer la lentitud escrupulosa de Wittgenstein, quien también alterna (en el lado izquierdo y derecho de sus Cuadernos) el ritmo preciso de sus juicios lógicos con las súbitas interjecciones del alma, los gemidos de angustia y las plegarias que profiere para sí. En los Diarios, la temporalidad abstracta de la filosofía regresa al presente de la existencia, y así pone a prueba su veracidad y validez. El filósofo procede minuciosamente en esta ardua introspección y examina así las estrategias que emplea su pensamiento.

San Agustín narra desde el presente de la escritura sus recuerdos. El despliegue de la memoria ocurre ante los oídos virtuales de un lector-testigo: la humanidad coetánea y futura. Son traídas al presente las respuestas de Dios, así como los diálogos internos del penitente consigo mismo. El texto sigue el protocolo de la confesión como rito sacramental, con sus distintos momentos de interpelación a lo divino, de auto-humillación, de plegarias y silencios penitenciales.

El ritmo del rito oracular, por su parte, responde también a un protocolo. Es la puesta en escena del contacto entre la dimensión atemporal de la visión divina, que no es sino la visión del ayer, del hoy y del mañana en un mismo plano e instante, con la visión restringida al presente, escurridiza e inmediata 
que tiene el hombre. Lo temporal se convierte en una cuestión espacial. Se trae a la consulta el futuro, pero también el pasado oculto o el presente ignoto; y se materializa en el lenguaje tanto lo fáctico como lo potencial entrelazados. La palabra oracular, siendo como es "palabra eficaz", mandato provocador de sucesos, genera además su propio devenir delirante; pasará por diversos estadios de interpretación y corroboración en los hechos, para trasladarse luego al tiempo cíclico de los mitos, al tiempo histórico de las citas literarias y los documentos, y finalmente al tiempo escénico de la tragedia. Su intrahistoria atraviesa los estadios del discurso irracional (mágico y religioso), del racional (jurídico, filosófico y político) y desemboca en el estético (a caballo entre la historia y el mito) para convertirse en operador poético. ${ }^{19}$

\section{La palabra como voz: manifestación del sujeto}

El sujeto que pronuncia una "palabra viva" no quiere ocultarse tras ella ni hacer desaparecer las inflexiones de su voz, cuya huella se imprimirá en la escritura. La voz implica un estado emocional, una textura sonora particular, un cuerpo concreto, un "estar ahí". El discurso se vuelve expresión directa de la existencia del sujeto; no sólo el estilo, en términos de retórica, sino también las referencias al enunciador como protagonista y a su circunstancia como escenario, lo "recuperan" como factor esencial del significado, y sobre todo como prueba de su veracidad y validez ética. Desafiando la objetividad, los textos que he estudiado integran la subjetividad como horizonte de verosimilitud y a la vez como estrategia para seducir a los posibles lectores.

\footnotetext{
${ }^{19}$ El discurso delirante de la Pitia será interpretado primero por los sacerdotes del Santuario; a menudo tal interpretación será discutida en el Senado, y acaso pasará luego a los escritos de historiadores y poetas coetáneos y futuros.
} 
Cuando Heidegger se coloca en uno de los polos de su diálogo, lo hace con un cuerpo que se mueve en el espacio, un estilo de habla, un modo de ejercer el pensamiento y una intención comunicativa particular: hacer participar al lector de su trasgresión al lenguaje. El sujeto filosófico, con toda su complejidad anímica y fisiológica, sus conductas e intencionalidad es para Wittgenstein, igual que para San Agustín, el instrumento mismo del pensar. Es necesario conocer, purificar y afinar ese instrumento para hacer una filosofía honesta. La subjetividad es acicate del rigor racional, de la búsqueda de la verdad. La introspección y la confesión del yo son una fase indispensable de esa búsqueda. Para conocer hay que "convertirse", dirá Wittgenstein. San Agustín actualiza en la escritura una situación tópica: la del autoexamen y penitencia en el desierto, que aparece ya en la Biblia y en otros textos antiguos no cristianos; pero el hecho de proferir esa experiencia desde el 'yo mismo' da nacimiento a un género literario: la confesión en tanto que manifestación escrita de lo que el hombre es. Pero la confesión no es sólo testimonio de la pequeñez del hombre sino declaración de la grandeza de Dios, cuya presencia es la fuente de sentido del texto en su conjunto.

Hay una importante diferencia de actitud entre el 'sujeto andante' de Heidegger y 'sujeto reclinado' de San Agustín y Wittgenstein, y ello incide en un estilo diferente de hacer filosofía. El primero resulta sereno y meditativo; el segundo, apasionado y fogoso, aun si sus autores se proponen ser meticulosos y racionales: el rigor y la precisión casi dolorosa de sus textos es un síntoma más de ese fuego anímico que arde en ellos.

San Juan de la Cruz no arde ni se consume en su poesía, más bien se diluye. La suya es una pasión que no le deja detenerse en cosa alguna. Sus 'ansias de amor' se concentran en un único fin, el Amado, arrastrando en su caudal todo otro deseo. $\mathrm{Su}$ padecer es activo hasta cierto momento ("la noche oscura") 
pero luego se torna fácil, entregado, pasivo pero vigoroso. El místico somatiza: lo que siente el alma lo vive el cuerpo. El lenguaje del poeta místico "somatiza" también y adquiere los síntomas de quien lo pronuncia. San Juan experimenta su alma individual como lugar de encuentro con la divinidad; es la interioridad más recóndita del sujeto la que puede ser visitada por el Todo; es ahí a donde se dirige, pues sólo ahí se encontrará con el Tú que le dará sustancia y forma. El autor del Cántico espiritual es un yo contingente que se deshace de sus anhelos, biografía, palabras e imágenes más caras para ser anegado por una Voz absoluta. La manifestación lingüística de este Sujeto-templo no son las palabras sino el canto que lo traspasa y en él resuena, como dolencia y curación.

La Pitia en Delfos desaparece en tanto sujeto pero prevalece en tanto que cuerpo y alarido; objeto parlante en manos del Dios, doncella poseída, virgen violada, el carácter "femenino" de su palabra se exaspera hasta la ininteligibilidad. No suscribe ni comprende lo que dice en su delirio, pero esta inconsciencia es prueba de la verdad oráculo, de su gratuidad e "inocencia".

La palabra como escucha: mediación con otras voces y otras esferas (el silencio, la espera)

La palabra viva depende menos de lo dice que de lo que calla; mientras discurre, dialoga, canta, o profetiza el sujeto enunciador "se vacía" de sus propios juicios y quejas para replegarse en una actitud de escucha: Su elocución va siempre sincopada por un silencio que aguarda la palabra del Otro, voz interna y trascendente. En el caso de Heidegger se trataría del Decir (un "Ello" que atraviesa al hombre); en el caso de la mística, se trataría del Amado (un "Tú" sagrado, que se vincula amorosamente con el hombre); en el caso de San Agustín sería Dios (un "Él” que atestigua y da sentido a la palabra hu- 
mana), en el caso de Wittgenstein, el Silencio (una "Nada" que custodia el sentido último de todo pensamiento), y en el caso de la Pitia (otro "Yo" "que la posee para transmitir una visión atemporal). El sujeto que abandona su personalidad (como un actor en escena) para dejar hablar por él a otras voces funciona también en la escritura como un medium entre esferas de distinta naturaleza. Escuchar y dar espacio a otras voces son las condiciones esenciales de la palabra viva —eficaz, itinerante, generadora de realidad, inagotada de sentidos - cualquiera que sea el ámbito o la disciplina en que esta palabra se manifieste (el arte, la ciencia o la filosofía). La palabra "teatralizada", poseída por aquello ininteligible, sagrado y misterioso que invoca, gana sentido en virtud de su silencio alerta, significante por sí mismo como en la música.

Este silencio está representado en Heidegger por el 'Claro' (lugar de advenimiento al que se llega mediante la especulación itinerante) y por la Serenidad (actitud de espera paciente para que se manifieste por sí sola la verdad), mientras que en Wittgenstein es el horizonte mismo de toda reflexión, límite que no debe transgredirse, para que el contenido mudo de ese silencio "resuene" en el propio pensamiento, dando sentido unitario a todo lo que pudiera "ser dicho". En San Juan de la Cruz, el acto de cantar la unión con Dios es ante todo un acto de escucha. Cantar es entrar provisionalmente en el caudal de una Voz en permanente ejercicio. La poesía mística es "dictada" por esa voz, y le hace tomar la pura forma y la ausencia de contenido característicos de la música. ${ }^{21} \mathrm{La}$ "escucha" de la

${ }^{20}$ Los oráculos de Apolo aparecen formulados en primera persona, la persona del Dios.

${ }^{21}$ En la música, la forma misma es el contenido. Y esa forma se caracteriza por ser vehículo de emociones: tensiones y alivios, pausas y reapariciones del sonido. La música (a diferencia de la lengua) ha podido dar al silencio un valor, una duración y lugar perceptible por el oído. Cuando el lenguaje hablado o escrito quiere hacerlo (es decir, hacer perceptible lo inefable, lo misterioso) debe recurrir a elementos "musicales": la entonación, la puntuación, el blanco gráfico, la métri- 
Pitia durante el trance consiste en abrir todo el cuerpo y la psique a las insoportables visiones que tiene Dios (las phantasías). En su garganta las visiones adquieren realidad sonora, pero las emisiones de su voz no dicen ni ocultan nada, "sólo lo significan", escribe Heráclito.

Así como en el teatro un actor representa a un personaje (proveniente del mundo de los muertos o de las esferas de la imaginación y el mito), hay textos como éstos cuyo acto primordial es escuchar, para trascender las intenciones individuales y alcances de su autor abriéndose a un dictado trascendental. Eso lleva a trastornar los procedimientos habituales del lenguaje, y a que su mera existencia como textos sea su significado esencial: Son epifanía.

La palabra en estos contextos "teatralizados" es pues una palabra en espera, una palabra pasiva, un signo que se niega a sí mismo para servir sólo de conexión sensible con lo sagrado, lo suprasensible. El choque entre lo contingente y lo trascendente le da necesariamente un carácter enigmático — no unívoco, ni cerrado a una sola versión. Así, la palabra oracular muestra y oculta al mismo tiempo, revela y engaña a los hombres, señala y extravía a los consultantes. Es ante todo palabra críptica, obtusa. Por su parte, la palabra poética de San Juan de la Cruz confunde las referencias temporales y espaciales, asegura y niega que la unión con Dios se haya realizado, se entusiasma con la promesa y se angustia con la ausencia del Amado. Es instrumento de "vocación" (llamada de lo sensible a lo espiritual) y de "desposeimiento" (desapego a toda sensorialidad, a todo nombre y cualidad). Esa misma ambigüedad radica en los conceptos que Heidegger va desgajando en sus diálogos, y que no llevan a conclusión filosófica alguna sino son sólo un tanteo efímero con lo inefable.

ca, la rima, el ritmo de una prosa, o a más sutiles procedimientos de "resonancia" semántica, como la metáfora, la metonimia y otras fórmulas retórica. Por eso decimos que la poesía es pensamiento y música fundidos. 
La palabra como tensión: antagonismo dramático entre sujetos o principios opuestos.

Así como en una pieza teatral las oposiciones ocurren a varios niveles (a nivel de la trama, de los valores, de la puesta en escena respecto de la obra literaria, etc.), hay en los poemas, narraciones y ensayos que he analizado diversos tipos de tensiones que dan origen al discurso y lo vuelven "problemático", "irresuelto", perturbador. Su carácter bullente hace del texto una provocación y foco de experiencia para el lector. La tensión que da vida a los diálogos heideggerianos es en primera instancia la confrontación entre dos hombres (Heidegger y el filósofo japonés), con sus distintas lenguas y bagaje cultural; pero no se trata de un duelo entre la visión occidental y la oriental, sino entre el pensamiento racional idealista y sus propios límites, método y lenguaje. Lo que está en juego es la búsqueda del ente (el ser-ahí, como noción existencial concreta), frente al Ser (noción abstracta y enajenada). También Wittgenstein lucha contra los "peligrosos experimentos que en la historia se han hecho a partir de la racionalidad abstracta". Sus apuntes íntimos y subjetivos, a la izquierda de sus Cuadernos, entran en contradicción con las especulaciones en la parte derecha. El hombre que vive y siente es antagonista del hombre que piensa, pero su expresión provoca una dialéctica más profunda y dramática en la conciencia del filósofo. El drama de quien se confiesa es la culpa, el odio hacia sí mismo, y la intensa necesidad de reconciliación. Lo que entra en antagonismo en las Confesiones de Agustín es la biografía fragmentaria del pecador y el sentido integral, atemporal de su testimonio. No son Dios y el hombre quienes se enfrentan, sino el hombre extraviado consigo mismo, con otra instancia de sí ya replegada ante Dios. Los actores del poema dramático en el Cántico espiritual: el Alma y el Amado, se encuentran y pierden, se persiguen y apresan uno al otro como en una cacería. 
El erotismo se expresa en toda su violencia y dulzura. La unión mística nupcial, dadas las distintas sustancias del alma humana y la divina, implica el despliegue de un antagonismo intrínseco que no osa tener un desenlace definitivo en el poema. La oposición entre Dios y el hombre en tanto naturalezas ontológicas distintas se analoga con otra tensión consustancial a la lengua misma, la distancia entre experiencia y expresión: ¿Cómo hablar de lo inefable sin traicionarlo? En el propio cuerpo de la Pitia se escenifica con mayor espectacularidad esta misma violencia del contacto entre lo humano y lo sagrado, entre el nivel histórico y el nivel transhistórico, entre la visión y la intelección que se funden en una profecía, haciendo estallar las leyes del lenguaje y la razón. Hay otros dramas en el corazón del rito oracular: la rebeldía de la conciencia frente a la posesión insolente del Dios y su voluntad, ${ }^{22}$ así como la contradicción de concebir que el destino está escrito - y es fatal por tanto-, y a la vez pretender manipular ese destino. La paradoja que da vida a la escena adivinatoria se verifica en términos temporales. Si bien la profecía se enuncia en el presente del consultante, despliega ante sus oídos una dimensión que no será capaz de comprender sino una vez que los acontecimientos predichos hayan ocurrido. Para colmo, la propia consulta y el oráculo forman parte de la cadena causal de esos acontecimientos. ¿Cuál sería el caso de situarse en posición de "ver" lo invisible y de conocer lo inevitable -inevitable en parte por haber sido 'mal conocido' de antemano? Esta paradoja es el eje del discurso oracular, y lo será también por cierto del género trágico, antiguo y moderno. ${ }^{23}$

\footnotetext{
${ }^{22}$ Es éste el drama de la legendaria Casandra, profetisa troyana, quien por haberse resistido a la posesión sexual de Apolo, recibe del dios el castigo de no ser creída jamás.

${ }^{23}$ El teatro de todas las épocas urde su trama en el choque entre predicción, expectativa falsa, y acontecer fáctico.
} 
El carácter agónico de los textos que he analizado descansa en sus propias dinámicas de pensamiento y creación experimentados como lucha. El lenguaje debe ingeniárselas para dar cuenta del lado oscuro de su escena, para "decir el silencio" sin decirlo. Se trata de un silencio tenso, elocuente, cargado de sentido que sólo puede hacerse resonar desde el margen de la hoja. Cada uno a su modo, estos textos dialogan con el silencio; en ello radica su intensidad emotiva y mental. Solemos asociar lo "teatral" con lo que se exhibe en espectáculo, y sin embargo la esencia de toda teatralidad es precisamente "dar a ver" lo escondido. La dramaticidad de estos textos reside en el hecho de entrelazar lo revelado y lo oculto en altísima tensión. Tal tensión nos sale al encuentro como lectores-espectadores y confronta nuestras propias contradicciones irresueltas, problematizando al revivirlos, nuestros juicios, memorias y sueños.

\section{La palabra como acto: transformadora y generadora de realidad.}

Heidegger cuestiona el proceder monolítico y abstracto de la tradición filosófica occidental y se arriesga a situar en el terreno de la intersubjetividad sus propias especulaciones sobre el Ser, el habla y el arte. Wittgenstein pone a prueba su pensamiento enfrentándolo contra el instinto, la emoción y la precariedad de la vida diaria. San Juan lleva a cabo un programa ascético hasta las márgenes mismas del lenguaje, mediante una poética de negación, donde los signos (metáforas, imágenes, nombres) se ahuecan para acoger al Verbo inefable. El rito oracular en Delfos mantiene el desafío de comunicarse con los dioses y el temerario afán de orientar el destino de individuos y Estados.

Filosofía, mito y poesía realizan diversas operaciones lingüísticas para entrar en contacto con lo incognoscible, y para ello se ven precisados a no intentar controlar la realidad que invocan, so riesgo de provocar todo lo contrario a lo que preten- 
den. Generan entonces textos de renuncia, textos en espera de una conexión genuina con Aquello a lo que interpelan, temen y ansían. En ellos la palabra tiene una función sacramental: hacer tangible, comunicable, una dimensión trascendente. Mediante el lenguaje se suscita entonces un acontecimiento de participación donde se anhela que "algo" inédito ocurra.

\section{La palabra como signo y referente: símbolo abierto, activo}

La búsqueda de teatralidad mostró cómo cambia el estatus de los signos dependiendo de la intención y estrategias comunicativas que se descubren en cada texto. Estamos habituados a considerar el signo, y particularmente el signo lingüístico, una entidad escindida en significante (presente) y significado (ausente). En el teatro, los signos lo son de sí mismos en primera instancia, de modo que lo oculto o ausente se manifiesta concreta y sensiblemente en una especie de transustanciación; también en estos textos las palabras, parlamentos y metáforas hablan de sí mismos en tanto que símbolos activos donde la experiencia con aquello que nombran se actualiza. El símbolo no está codificado como el signo sino que permanece fatalmente abierto a la intersubjetividad, y desde esa inestable sustancia suya puede acaso procurar la movilización de la sustancia psíquica en la mente del autor y el lector.

La escritura poética de San Juan es la vía misma de su ascesis (y no ilustración de un "programa" espiritual); el diálogo que escribe Heidegger es la forma misma de su reflexión (y no su exposición didáctica); la confesión de San Agustín o de Wittgenstein son el rito de autoexamen y purificación que se cumple en el lenguaje (y no la narración crítica de los hechos); las profecías de la Pitia son mandato directo del dios sobre la realidad (y no especulación sobre lo probable). La escritura opera en el sujeto que escribe y por resonancia opera también en el cuerpo del interlocutor. 
Estudios cognoscitivos sobre la percepción han intentado explicar cómo un objeto o imagen se convierte en lo que llamo aquí símbolo estético, es decir, "espacio" en que se revive una circunstancia y se la puede remodelar indirectamente. ${ }^{24}$ En estado de trance semihipnótico, explican los psicoanalistas eriksonianos, una situación psicológica muy compleja puede simbolizarse en una figura cualquiera para ser trasformada deliberadamente en tanto figura misma por la imaginación del paciente; es asombroso cómo la modificación del símbolo incide sobre la circunstancia en cuestión. Este estado de trance guarda similitud con los estados de meditación, de éxtasis, de duermevela o de simple arrobamiento estético: en todos ellos se agudiza la percepción, aunada a una autorreflexión distanciada. Es entonces cuando un objeto, una figura, una imagen o una palabra pueden volverse símbolos maleables en la "imaginación material" a la que se refiere Bachelard. Un texto que tenga la habilidad de crear un estado anímico propicio para la identificación y distanciamiento del interlocutor está generando espacios simbólicos que operan sobre su mente y fisiología.

Cuando Heidegger "dibuja" la noción de un "Claro" en el bosque invoca un estado de incertidumbre y espera; cuando piensa un camino nos lleva a avanzar con él; cuando se adentra en el bosque nos reubica en la espesura como horizonte cambiante de la conciencia.

Al cantar "mi Amado, las montañas, los ríos sonorosos, el silbo de los aires amorosos", San Juan de la Cruz infunde en nuestros oídos la dinámica airada de signos que se desdicen

\footnotetext{
${ }^{24}$ Los casos que reporta el Dr. Ramchandran (op. cit.), muestran cómo la imagen dibujada de una rosa basta para provocar un acceso de asma en ciertos enfermos. O cómo una dosis de sacarina, inyectada a ratas durante las primeras sesiones de un experimento junto con una sustancia inmunodepresiva, queda asociada - lo mismo que una metáfora- a los efectos de dicha sustancia y basta luego para deprimir el sistema inmunológico de los animales. La sacarina y la imagen de la rosa actúan como símbolos activos. Conocemos también el efecto placebo, donde la supuesta función de un medicamento es "inventada" por el lenguaje.
} 
después de aludir por un instante a la mirada, al reflejo, al abrazo del Amado; y esta experiencia de lo inasible cautiva al lector al tiempo que ocurre en los versos, incitándolo a cantar al unísono; ya no importan las palabras o imágenes, sino este impulso centrípeto y centrífugo que las arrastra, este "giro" que encarna la escritura. Los símbolos poéticos "hacen" la vivencia de la velocidad y el giro que nos saca de nosotros y nos hace regresar a una oscura interioridad donde se funden el abandono de sí y el anhelo por el Otro.

Cuando Wittgenstein escribe la palabra "silencio" impone a su pensamiento y al del lector un límite, sugiere así una ruta ulterior a la intuición, al instinto. Cuando San Agustín habla de "memoria" invoca un ámbito de lenguaje donde la luz de la visión divina inunda la palabra confusa del hombre. Cuando la Pitia prefigura la escena del parricidio y el incesto ante Edipo, su narración abre la identidad del consultante a la problemática de la filiación y la legitimidad.

Si la palabra poética entra en mí, lo hace como un organismo que cultivo, domestico o enardezco en mi propia conciencia y cuerpo. Ésa es mi libertad de lector y es también el peligro que corro en el estado "alterado" de percepción estética; estado que implica una lucidez vacilante, activa y pasiva a un tiempo. Activa porque elige. Pasiva porque aguarda.

\section{La palabra como organismo cambiante}

Decía Artaud que en el teatro las palabras deben tener la misma función que tienen en los sueños, una función emblemática, de proferición, de provocación.

En Heidegger la palabra actúa como señal, como orientación de un curso que el pensamiento ha de seguir sin detenerse en nociones que el lenguaje tiende a fijar dentro de un sistema. La operación poética, en cuanto recurso para invocar lo ausente, el Ser mismo, consiste en atravesar dichas nociones, desga- 
jándolas con el impulso de la marcha. Los signos son como piedras en las que se apoya la punta del pie para cruzar el río. La palabra es en efecto la "morada del ser", pero se trata de una morada itinerante.

Para Wittgenstein las palabras son como las fichas en un juego de interlocución, moneda de intercambio en una compleja relación comunicativa. Su significado depende del "juego del lenguaje" en que se actualizan y de los roles que adop$\tan$ los sujetos que las pronuncian. La operación poética en su caso es una auténtica deconstrucción del decir, y actualiza la paradoja (y la angustia) entre la búsqueda de la expresión precisa y la conciencia de que en sólo en el silencio radica la verdad.

Para San Agustín la palabra es un gesto sacramental, objeto sensible donde el sujeto se manifiesta: la escritura confesional es desnudamiento, testimonio y purificación. Narración, invocación o argumento son meras fases de ese proceso. La operación poética tiene también aquí un efecto paradójico: la exhibición de sí mediante una pormenorizada confesión no es más que repliegue del yo y de sus juicios ante el Verbo que "significa" más allá de todo lo que puede ser confesado. "Ante lo que no se puede decir, hay que callar" dirá asimismo la proposición última del Tractatus de Wittgenstein.

El Silencio, la salida (éxtasis) fuera de los terrenos del lenguaje no es para San Juan el límite u objetivo final, es el punto de llegada. Ahí, en la noche oscura del alma que ya no atesora ni la imagen ni la noción ni el nombre de Dios, es donde se hará presente su Voz. La operación poética es el vaciamiento sistemático, y ese vaciarse de contenidos tiene por estrategia la música. El dolor que implica el abandono continuo de los signos - desposeerse de la ostia, el sacramento, la plegaria, el recuerdo de la unión (“Ay, ¿quien podrá sanarme?”)— encarna la paradoja entre experiencia mística y expresión verbal.

El carácter indudable de proferición que tiene la palabra oracular crea en el escucha el propio destino por el que indaga. 
$\mathrm{Su}$ formulación en forma de enigma activa la paradoja entre la existencia ciega y la conciencia adquirida vía el lenguaje. El sentido de la vida, el Hado, no se revela ante el hombre sino en un acto dramático de reconocimiento. Esta ceguera de sus actos expuesta al develamiento de lo luminoso por el enigma oracular es el núcleo de la tragedia antigua y se retoma en el teatro de todas las épocas. Más que el "ser o no ser" de Hamlet, o el angustioso "ser o parecer" de un Pirandello, el teatro como ritual tiene en su origen la contradicción entre "ver y no ver" que el oráculo habría fundado. Saber para Heidegger es ver. Saber para Wittgenstein es callar. Saber para San Agustín y San Juan de la Cruz es escuchar. Saber, en la dimensión oracular implica enceguecer ante la visión del dios.

Una característica común de estos textos es que echan mano de una sinestesia extensiva, es decir, expresan los efectos correspondientes a uno de los órganos sensoriales o facultades cognoscitivas, en términos de otro. Se formulan percepciones visuales en términos auditivos, o auditivas en términos táctiles, o anímicas en términos olfativos, o procesos mentales en términos visuales e incluso kinestésicos (referentes al sentido de movimiento corporal en el espacio). Esto, más que ser un mero recurso retórico o esteticista, tiene un efecto curioso en los signos: por un lado, les hace volver de la abstracción conceptual a la concreción de una sensación corporal, invocando asociaciones arquetípicas asociadas con las necesidades primarias y la "imaginación material"; y por otro, deconstruye las habituales denotaciones de una palabra al transferir su campo de referencia: abandona así la experiencia estereotipo asociada a una palabra o imagen, para crear una experiencia aún por explorar.

Es evidente que el uso de procedimientos poéticos modifica el ejercicio científico, filosófico, y de artes no literarias, e incide en la reconfiguración de cualquier género discursivo. Así, el texto de Heidegger se separa del caudal monolítico del dis- 
curso filosófico y de la tradición literaria del diálogo —en tanto que mera estrategia didáctica o expositiva; y los escritos de Wittgenstein desarticulan la filosofía como sistema o código de contenidos para convertirla en un quehacer continuo de deconstrucción crítica. Agustín, al inventar el género confesional se aparta de la tradición de los hipomnemata ${ }^{25}$ de los estoicos e inaugura una nueva operación escritural que realiza el acto mismo de penitencia y purificación. San Juan se aparta de la tradición mística sufí, islámica, judía y cristiana cuando convierte a su escritura en encarnación de un programa ascético y en espacio sensual de unión con el espíritu.

\section{El efecto "teatral" en el lector}

Quien lee los diálogos de Heidegger es víctima de la misma suspensión de la certeza que sufren los personajes y es testigo de una erosión perturbadora de las palabras, que no lleva sino al vacío fascinador de la espera. Quien se halla frente a la narración confesional de San Agustín, o frente a la introspección in situ de Wittgenstein asiste al drama de una conciencia que se escinde entre las emociones y el pensamiento, entre la culpa y la fe, entre la crueldad con uno mismo y la esperanza. Quien consulta un oráculo buscando guía o consuelo sufre los terrores frente al sino y sin embargo se entrega a la peligrosa y sensual ilusión de ser protagonista de su propia historia, y no un títere en manos de la Necesidad. Quien participa de los cantos místicos se ve arrebatado por su propio impulso de autonegación y afirmación ulterior en otra esfera.

Pese a su aspiración unitiva, de trascendencia, todos estos textos no hacen sino revivir el drama del hombre, a quien no le

${ }^{25}$ Cuadernos de autoexamen con apuntes diarios, como los que dieron nacimiento a las Meditaciones de Marco Aurelio, y que se recomendaban como estrategia importante del "cuidado de sí”, aspecto crucial del conocimiento filosófico. 
basta su propia palabra ni para expresarse ni para comprenderse a sí mismo. Aunque comparten una aspiración metafísica, regresan una y otra vez al cuerpo y a la piel. Su efectividad "ritual" depende de que puedan transferir sensaciones vivas al lector, provocar la catarsis, propiciar una anagnórisis, alternando las dinámicas de identificación/distanciamiento como hace una representación teatral. Así, el texto crea un espacio de mediación no tanto entre autor y lector, sino del lector consigo mismo. Hace de la lectura una forma privilegiada de intimidad, abierta a otras voces y perspectivas; una experiencia de ensanchamiento de la subjetividad. Leer es hablarse en soliloquio con palabras nuevas, si el lector se deja envolver por las dinámicas que genera el texto. No hay verdadera comprensión sin participación, sin contaminación. Si bien la literatura produce en nosotros ese efecto de distancia y perspectiva que nos libera, la liberación ha de pasar por todo nuestro cuerpo y mente para cumplirse. El texto ha de carearse con la existencia concreta porque si no es letra muerta. La ficción inherente a todo discurso, es decir la creación de un mundo autónomo escritural, nos "protege" de las realidades que el texto toca en nosotros: como en el teatro, sabemos que lo que vemos en escena es cierto y que no lo es, a un tiempo. En esta duplicidad entre lo fáctico y lo virtual con que juega la ficción radica quizá nuestra única libertad, si no de controlar al menos de comprender las cosas que nos suceden. El camino de vuelta a la unicidad entre existencia y conciencia sería quizá nuestra salvación, pero implica atravesar un drama intenso que el arte puede sólo plantear pero no resolver. 


\section{Bibliografía}

Aristóteles, Poética, Icaria, Bosch, Barcelona, 1987.

Bachelard, Gaston, La poética del espacio, Breviarios del F.C.E. \#183, México, 1965.

Dürrenmatt, F., La muerte de la Pitia, Tusquets, Barcelona, 1990.

Elam, Keith, The Semiotics of Theatre and Drama, Methuen, Londres, 1979.

Heidegger, Martin, "Debate en torno al lugar de la Serenidad", en Serenidad, Odós, Barcelona, 1967.

— "Diálogo entre un inquiridor y un filósofo japonés", en De camino al habla [1959], Odós, Barcelona 1988.

- Caminos del bosque [1984], Alianza, Madrid, 1995.

Kott, Jan, El manjar de los dioses, Era, México, 1977.

Margules, Ludwik, Apuntes del curso Teoría y metodología de la dirección teatral, impartido en el Núcleo de Estudios Teatrales, México, 1988.

San Juan de la Cruz, "Cántico espiritual" y "Noche oscura del alma", en Obras completas [1929], Archivo Silveriano, Ed. Simeón de la Sagrada Familia OCD, Burgos, 1972.

San Agustín, Confesiones, Círculo de Lectores, Barcelona, 1971.

Ramachandrán, Fantasmas en el cerebro, Ed. Debate, Madrid, 1999.

Ubersfeld, Anne, L'école du spectateur, Ed. Sociales, París, 1981.

Wilshire, Bruce, Role Playing and Identity: the Limits of Theatre as Methapore, Indiana University Press, Bloomington, 1982.

Wittgenstein, Ludwig, Diarios secretos [1961], Alianza, Madrid, 1991.

Wolf, Christa, Cassandra, The Noonday Press, N.Y., 1984. 